\begin{tabular}{|c|c|}
\hline \multirow{3}{*}{ 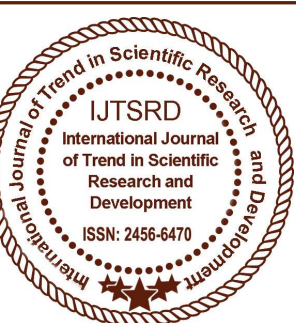 } & $\begin{array}{l}\text { International Journal of Trend in Scientific } \\
\text { Research and Development (IJTSRD) }\end{array}$ \\
\hline & International Open Access Journal \\
\hline & ISSN No: 2456 -6470 | www.ijtsrd.com | Volume - 2 | Issue - 3 \\
\hline
\end{tabular}

\title{
Awareness Needed to Protect the Child Rights in India
}

\author{
Kuheli Bhattacharya \\ Presidency University, \\ Bangalore, Karnataka, India
}

\section{ABSTRACT}

India comprises of a huge amount of Population. Among the huge population more than half comprises of children. Children are most beautiful gift of the society. And the rights that should be given to the children that are not being provided to them properly, they are deprived of their rights. That is the biggest problem of India which makes India lag behind. So to make our country more developed and strong awareness should be provided to the people of India. Awareness should also be provided so that the children can enjoy their rights as well as their childhood.

The motive of my research is that mainly the rights of education is being violated in a large extent today, child labour is also in a great force in India children below the age of 14 are found working in hazardous places which is strictly prohibited by article 24 of the constitution, child marriage is still prevailing in many places of India. So there is a much need for the awareness to be provided in order to protect the child being deprived of their rights as they are future of our society and no one has the right to snatch it from them.

I am going to adopt the doctrine research methodology for my research. The data's and information's will be provided from a relevant source.

From this research it will be helpful for me to give some suggestions as well as relevant solutions regarding the problem.

\section{INTRODUCTION}

Children are the main group of the citizens of India. They are the future of the present society. So they should be protected in every special and possible way to build the future of the country strong. There are certain rights provided for the children in order to give them equal status in the society as well as many provisions are being done in order to provide them prior education, to bring them up to the society as because they are the only key who can make the future bright.

But there rights are only not provided to them properly. The children below the age of fourteen are not allowed to do any hazardous work as per the Article 24 of the Constitution. As well as children are not allowed to work in any construction site. But what is happening in our society? In the construction sites the children are found as labour. In many shops they are found working and even treated very badly by the masters on the mistakes done by them, and they are forced to work only because they have to maintain their family. Even if education has been made compulsory they are not allowed to attain proper education. Hereby our society lags behind. That's why proper awareness is required in India as because if these children will only be not able to grow up properly then there will be no future of India. It will be still developing and can never become developed. The awareness is also required in order to provide the children a perfect childhood and so that no one can snatch it from them. Awareness should be made, "for the children should be protected as they are the beautiful gift of the society and the coming future of the country". 


\section{CONSTITUTIONAL PROVISIONS PROVIDED FOR THE PROTECTION OF CHILD RIGHTS}

There are many provisions provided to protect the rights of the citizens of India. The Part III of the Constitution of India provides about the various provisions about the Fundamental Rights that are to be provided to the citizens and are equally required to be performed by the citizens. The state works on to protect the rights given to the citizens. Article 19 of the Part III of the constitution of India provides about the various freedoms that are to be given to the people of India but it is provided with reasonable restrictions. In the Article 15 of the Part III of the Constitution provides that there should not be any discrimination against the people only on the basis of caste, sex, race, religion, place of birth or any of them. Thereby the Article 15(3) states that there should be some special provisions made for children.

Article 23 of the constitution of India provides about the prohibition of traffic in human beings and forced labour. Herein it says that traffic in human beings and beggar and other similar forms of forced labour are prohibited and any contravention of this provision shall be an offence punishable in accordance with law 1 . Here in this article 23 of the Constitution of India it is not perfectly mentioned about the children section of the society but since in India there is a large amount of population still existing who are still backward especially in the rural areas, where the proper education for family planning has still not reached so in such areas families ends up having more than two children and for whom the parents are unable to provide proper livelihood. This ultimately results in the children below the age of maturity to mature enough so that they can help their family. This is a clear violation of their rights as well as their childhood. In the age of enjoying their childhood, they are forced to earn for the family and that also in such an age when they don't even understand the meaning of earning. And this benefit is enjoyed by the masters who appoint them as their workers and make them work beyond their ability for more hours and don't even remunerate them properly. And where the word "beggar" comes which means when somebody is

\footnotetext{
${ }^{1}$ D.D.BASU's, "Introduction to the constitution of India”, page no. $123,21^{\text {st }}$ edition, para 3
}

made to work without any remuneration. And in few judgements it is also interpreted that even if the employers are not provided with enough remuneration is a clear violation of article 23 of the Indian Constitution. But yeah there is always a reasonable restriction provided for every aspect of the provisions of the Indian Constitution and so there is also an restriction provided for this provision also which is provided under the 23(2) which says that nothing in this article shall prevent the State from imposing such service for public purposes, and in imposing such service the State shall not make any discrimination on grounds only on religion, race, caste or class or any of them. In the ancient times of India there was not so much problem with the system of "slavery" but by the new provisions which are made by the Constitution of India has changed the full concept of Slavery and had mentioned as "human trafficking" and had declared it as a very serious challenge to human freedom and civilisation. The framer of Indian Constitution has used the term human trafficking in place of slavery as because it includes prohibition of trafficking in women or children or the crippled, for immoral purposes and not only for slavery. It also includes trafficking of girl child and women who are from very poor background, and who are in a need of money and so they can easily be influenced by providing money and those people at last find their position in prostitution, pornography and now-a-days there is a lot of news spread about child sexual abuse which is another biggest crime as well a violation of their rights and innocence.

Now coming to the other set of rights that are provided for the children section of the society. According to the Article 24 of the Constitution of India no children below the age of fourteen years, shall be employed to work in any factory or mine or engaged in any other hazardous employment ${ }^{2}$. The prohibition that has been provided under this article is absolute and dose not admits to any exception for the employment of a child in a factory or mine or in any other hazardous employment like that of in a railway or a port. The Supreme Court directed that children should not be employed in hazardous jobs in factories and positive steps should be taken for the

\footnotetext{
${ }^{2}$ D.D.BASU's, "Introduction to the Constitution of India”, page no. 123 , para 6
} 
welfare of such children as well as improving the quality of their life and the employers of children below 14 years must comply with the provisions of the child labour (prohibition \& Regulation) Act providing for compensation, employment of their parents/guardians and their education ${ }^{3}$. In spite of this prohibition in the constructions sites more number of children is found working than the others. And even in fire cracker factories there are a lot of child labours found especially only children are found mostly working as because they does not have the ability to question back to their masters even if they are treated badly, not enough remuneration are not provided, or even if they are forced to do certain works. So this is again a clear violation of their fundamental rights.

Now coming to the most crucial part of a children's life that is "education". Now-a-days there has been a lot of improvement made in the fields of education in India especially to uplift the backward sections of the society as well as the girls of the society. In the recent years the literacy rate has shown a great increasing rate. The Constitution (eighty-sixth) Amendment Act, 2002 has inserted Article 21A which provides that the State shall provide a compulsory education to each and every child of the age six to fourteen years in such a manner that the laws of the State may determine. Every children of the country has the right to gain a quality education without any discrimination on the basis of the child's background. It has been made a part of the Fundamental Right by including in the part of Article 21 of the Constitution. If there is total government interference in this provision then it is a clear violation of the fundamental rights of the children. In spite of this much improvement there are a number of children even today who does not even get a chance to see schools whose life starts with carrying a sack in the shoulder along with a lot of unknown responsibility in spite of school bag and responsibility of home works. This is again a clear violation of their rights which is the most crucial part of a children's life. It is the mode of development of a child to be a proper human being and make themselves presentable before the society and compete others at the same level. But if due to

\footnotetext{
${ }^{3}$ D.D.BASU's, "Introduction to the Constitution of India", page no. 123, para 7
}

certain problems these children cannot reach the boundary of the school then how can the country expect a future from the new generation which are mainly comprised of the children.

There are also many other violation of rights that are done against a child includes child marriage which is a very crucial problem which need to be removed from the society's each and every corner. Child marriage exploits the whole childhood of a girl, as well as brings a break down in the society.

\section{A STEP FPRWARD TO CREATE AWARNESS IN INDIA FOR PROTECTION OF THE CHILD RIGHTS}

There are several steps taken to provide awareness against child right violation. Various organisations both governmental and non-governmental are putting their hands in hands together to bring out full protection of the rights provided to the children as well as to inform them about the operation and violation of their rights.

The initiative taken by worldwide to protect child rights: The League of Nation was established in order to protect child rights. The UN Fund for Urgency has been established in order to protect the children that were affected by World War II, which is now known as UNICEF. The UN declared the year of 1979 as International Year of the Child. The commissions for the Protection of Child Rights Act,2005 provides for constitution of National/State Commission for the protection of child rights and children's Court for providing speedy trial of offences against children or violation of child rights ${ }^{4}$

Steps taken by government of India to protect child rights: the government of India has provided with several measures in order to maintain the child rights. The Constitution of India has made several provision in order to prohibit the violation of rights of the children. The Directorate of Social Welfare is has been enforced in order to act upon certain legislations for protecting children and their rights ${ }^{5}$. The government of India has provided several acts to protect the child rights, they are as follows ${ }^{6}$ :

\footnotetext{
${ }^{4}$ IOSR Journal of Humanities and Social Science

${ }^{5}$ IOSR Journal of Humanities and Social Science

${ }^{6}$ IOSR Journal of Humanities and Social Science
} 
The National Policy for Children, 1974

Immoral Traffic Prevention Act, 1986

Child Labour (prohibition \& regulation) Amendment Act, 2016

Prohibition of child Marriage Act, 2006

The right of children to free and compulsory Education Act, 2009

The protection of Children from Sexual Offences Act, 2012

The Juvenile Justice (care \& Protection) Act, 2015 is the comprehensive and principle Legislation in India for the protection, growth, and development of children. The CHILDLINE launched in Mumbai in 1966, presently operating almost in 372 cities/34 States in India is a toll-free tele-helpline for children in distress across India. There are various schemes introduced by government for the welfare of children among them two are Integrated Child Development Service(ICDS) and Integrated Child Protection Scheme(ICPS).

\section{NEED FOR AWARENESS TO PROTECT CHILD RIGHTS IN INDIA}

India is the only country where there is a huge amount of population of Children. And children are regarded as those groups of the Society which can bring in changes in the future and make it more developed and beautiful. So as they built the future of the whole Country they are most vital part of the society and so they are needed to be protected in all ways possible. There is a very important reason for protecting their rights. They should be provided for best quality education which is there fundamental rights which is being guaranteed by the constitution and it should be strictly provided to each and every child because education is the base of their development. Without education they cannot make them comparable among the society. They cannot become equal to the others of the society. And so to bring them in the same position in the society education is very much needed to be provided to them. The children are now sexually abused and their trafficking are done and they are forcefully brought into the field of prostitution in name of giving them proper education along with job and separating them from their parents and this way their rights are deprived and their life is made pathetic. So for this there is a very much need of creating awareness among them about the possibility of losing their child in name of giving them better life. The parents as well as children should be made aware of the fact that they should not get influenced by anyone who confirms them of taking them in a good place and give them a job as well as providing them with education. They should be aware of good and bad motive of the people who are surrounding them to destroy the little hearts. Awareness should also be provided about compulsion of education all over especially in places where people does not know the benefit and requirement of education and so they should be made aware of such facts and the laws that provides the compulsory education for children, and so they should send their off springs to school without failure. And still today in India there are a lot of families who cannot afford providing education to their children, so for this problem the government should provide certain benefits to those families so that their children also get the compulsory education and their rights does not get violated. Now coming to another major problem of the society that is child marriage which is a main danger for the little girls whose childhood is totally destroyed and their full life is deprived of rights. So in this case providing punishment is not any perfect solution rather there should be steps taken forward in order to provide information and education to the people that what are the demerits of child marriage and how it affects a child"s life. Why there is an age limit has been provided by the Indian Laws for marriage. If they get married in small age then how their rights are violated and how it destroys a life. And if such awareness can be provided to them in a proper way then no parents will want to destroy their children "s life. As because at the end of everything no parent wants their children to be deprived of anything, so they will understand the needs of the rights that there children should enjoy and will themselves come forward to provide their children with the rights. Now coming to the next problem that is child labour which is the worst part of the deprivation of their rights. The children should not be allowed to work in any place until they reach their age of maturity or to such a age that they can understand the meaning of responsibility and also be able to take responsibilities. The way of treatment the masters 
give them should be stopped and also severe punishments should be provided for them as because they are aware of all the laws of the Country then how can they involve them in depriving their rights in spite where they can be the one who can help them to get their rights. And also they should be provided with perfect remuneration and there should be awareness camps made for providing family plan education to the peoples as because this is the main problem of child right violation.

The steps that can be done for providing awareness to the people are:

1) Awareness camps should be organised for providing education about the child right prospects.

2) Government should provide special help and schemes for helping the poor people to provide the children proper education.

3) Family planning education should be provided widely.

4) A checking programme should be organised to keep a check on child labour, child sexual abuse, child right violation, child marriage, and other problems to save guard the child rights.

5) In schools the teachers should make some programmes to make the students aware of all the aspects and so that they can contribute to the same.

\section{Conclusion}

As per mentioned before also that children are the future generation of the society and so they have the full right to live in a safe and protected environment. And if they cannot be protected as well as assured with their rights then they cannot become developed and become a proper member of the society. So there should be enough steps taken in any way possible to assure them a good and secured environment. (1) 